\title{
The Exploration of Modern Apprenticeship in Higher Vocational Art Design Major
}

\author{
An Wang, a , Hao Lu ${ }^{2, b}$ \\ ${ }^{1}$ Jiangxi Science \& Technology Normal University, Nanchang, China \\ 2 Jiangxi Vocational \& Technical College of Information Application, Nanchang, China \\ awanganwangmenghua@163.com; 'lh880223@163.com
}

Keywords: modern apprenticeship; personnel training; art design major

\begin{abstract}
In recent years, the demand of employment market for art design talents has continued to rise. It is an important task for higher vocational colleges to cultivate more high level and high quality skilled talents. However, there is a big gap between the quality of the students in the art design specialty and the demand of the economic production practice. Serious imbalance exists in the supply and demand of talent, which shows that traditional teaching mode has some problems. Practice has proved that modern apprenticeship in art design major has achieved good teaching effect. So the paper makes deep research on the implement of modern apprenticeship system in art design major of higher vocational university.
\end{abstract}

\section{Introduction}

In recent years, the demand of employment market for art design talents has continued to rise. It is an important task for higher vocational colleges to cultivate more high level and high quality skilled talents. However, there is a big gap between the quality of the students in the art design specialty and the demand of the economic production practice. Serious imbalance exists in the supply and demand of talent, which shows that traditional teaching mode has some problems. So higher vocational colleges need to explore and innovate teaching mode to meet the needs of personnel training in the new era. Practice has proved that modern apprenticeship in art design major has achieved good teaching effect. Higher vocational colleges explore the reform of art design talent training mode by introducing modern apprenticeship, and this can effectively increase students' technical level and further promote the close connection between talents training and social demand.

\section{The connotation of modern apprenticeship system}

Modern apprenticeship has developed on the basis of absorbing the advantages of traditional apprenticeship and integrating the advantages of modern occupation education since 1990 in developed countries represented as Britain, Australia and so on. It is very effective to solve the disconnection between theory and practice, knowledge and ability. Compared with traditional apprenticeship, modern apprenticeship has the following advantages. First, it has unified education and training standards. Second, its participant includes government, industry, enterprises and schools and each plays different function. Third, it adopts the training mode of "work-integrated learning". Students learn theory knowledge in classroom while applying it in the production line. 
Fourth, training time is flexible. Students can choose study time and communicate with teachers and business leaders through modern communication means. Therefore, modern apprenticeship is fully in line with the needs of the society for professionals and has the significance of promoting the development of higher vocational education.

\section{The significance of modern apprenticeship system in higher vocational art students}

It is the urgent need for training skilled personnel in art design major of higher vocational colleges. With the development of cultural creative industry market, the demand for technical talent in art design specialty is obviously ascending. However, there is a big gap between the quality of the students in the art design specialty and the demand of the economic production practice. Serious imbalance exists in the supply and demand of talents. The personnel training mode of modern apprenticeship allows the students to master practical skills and the cutting-edge technology in the industry through direct teaching, which better adapt to the needs of the labor market than the simple school education and cultivate more advanced technical talents with higher theoretical level and practical ability.

It promotes the innovation of talent training mode of art design specialty. The existing higher vocational talents training mode of art mainly focuses on "school-enterprise cooperation", "work-integrated learning”, "studio" and so on. The construction of modern apprenticeship strive to build a mode combined the education of art design talent and the social practice.

It is the urgent need to inherit and carry forward the national traditional culture. Chinese is an ancient civilization with a long history. Studying the modern apprenticeship of art and design education can not only inherit and carry forward the national traditional craft and art with a long history in our country, but also maintain a certain academic value in the research of art and design academic integrity, so as to the talent cultivation of higher vocational education develop to the benign trend and deliver more skilled personnel closer to the market.

\section{The implementation of modern apprenticeship system in art design of high vocational school}

Establish the dominant position of the enterprises. The modern apprenticeship system is built by the school and the enterprise, so it is necessary to prepare before the modern apprenticeship system. The school should make the cooperative enterprises have full understanding and enthusiasm on the modern apprenticeship system through in-depth contact and close docking according to the specific situation of art design professional employment enterprises. Then under the premise of mutual benefit, study enrollment and recruitment policy with cooperative enterprises. There are a small number of enterprises in the demand for art design talents, so it is very important for schools to choose cooperative enterprises and build relevant enterprise groups, especially establish the dominant position of the enterprises.

The school and the enterprise make personnel training plan together. The personnel training plan is the programmatic document about teaching quality, talent training specification, teaching process organization, teaching arrangement. It is not only an important embodiment of professional orientation, but also the basis for the organization and management of teaching process. The personnel training plan, made by the school and enterprise together, can let the curriculum more reasonable, more scientific, and more targeted. Both sides should analyze the factors affecting students' growth and seek the meeting point between the occupation demand and the students' development, according to the basic rules and particularity of high skilled personnel training and the characteristics of art design major. At the same time, in order to ensure the talent training plan and the enterprise talent demand unanimous, the training plan should be made on the basis of full 
investigation and demonstration.

Develop the core courses suitable for modern apprenticeship teaching according to the professional standards and technical standards of art design. Determine the professional training objectives and main courses according to the investigation and analysis of employment. Organize professional teachers and part -time teachers to carry out project reform on the curriculum, so as to integrate the knowledge into the project to realize the integration of theory and skills and improve the students' learning initiative and enthusiasm in the way of project driven. In the construction of the core curriculum, school teachers and part-time teachers must discuss the knowledge and skills which must be mastered according to the occupation activities involved in the curriculum, and introduce the occupation standard to make the curriculum standards; select typical design as curriculum content carrier and design teaching contents and design project; complete the task of compiling the school-based teaching materials, making courseware, designing the library and so on.

Establish long-term mechanism of modern apprenticeship system. First, take special school-enterprise cooperation organization as security. Invite the experts in the art industry and enterprises, and the backbone teachers of vocational universities to establish relevant working group, so as to provide consultation for teaching design, curriculum design and personnel training and promote the effective operation of the school-enterprise cooperation and modern apprenticeship system. Second, give full play to the role of industry organization in the joint development. Arrange special organization and connect with the art industry, enterprises and organizations to make more and more enterprises to join the enterprise groups and let the industry, enterprises and organizations to send representatives to participate in school enrollment, recruitment, teaching, evaluation and other aspects. Third, the legal safeguard. The schools and enterprises sign contract in line with the principle of equality and mutual benefit to clearly the rights and obligations of both sides and protect their legitimate rights and interests, so as to ensure the long-term stable cooperative relations between schools and enterprises.

Construct personnel training quality control system. The schools and enterprises develop the personnel training quality standards together, so the teaching quality monitoring must also be implemented together. Construct the teaching quality evaluation system of the society, enterprises, schools and students. First, course quality monitoring. Invite industry masters and enterprise experts to form a special evaluation group to do special assessment on professional setting, curriculum development, training studio outside the campus. Second, training quality monitoring. Invite the government, industry and business representatives study on the problems existing in the construction of specialty and curriculum and in the teaching and personnel training. Strengthen the quality control of the training base outside the campus, to monitor the working conditions of teachers and students in the training base. Fourth, introduce the four evaluations. Collect the evaluation opinions on personnel training from the industry, employers, parents and graduates through a wide range of ways, laying good foundation for the organization of the third party evaluation.

\section{Summary}

Modern apprenticeship is fuse the traditional apprenticeship and modern higher vocational education theory, combines the theory and practice of classroom well, pays attention to the cultivation of personality development, conforms to the requirements of occupation education in the new age, therefore, it has great development potential.

\section{References}

[1] Xiuqin Hu. Study on the mode of modern apprenticeship system[J]. Journal of Hebei Normal University, 
2009(3).

[2] Guofeng Ye, Tonglin Xu, Baoping Zhou. Study on work-based learning talent cultivation model in higher vocational art design[J]. Packaging World, 2008(05).

[3] Zheng Gang. The enlightenment of Bauhaus workshop to contemporary art design education[J]. Journal of Nanyang Normal University, 2010(10).

[4] Wanyu Lu. Research on the talent training mode of modern apprenticeship in higher vocational education[J]. Dalian University, 2011(06).

[5] Junhua Xie. Discussion on the talent training mode of modern apprenticeship in higher vocational education[J]. Vocational Education Forum, 2013(16).

[6] Di Zhang. Research on modern apprenticeship system in architecture specialty of higher vocational university[J]. Chinese Educational technology and equipment, 2013(3). 